\title{
CIP program u Bosni i Hercegovini: iskustvo Nacionalne i univerzitetske biblioteke Bosne i Hercegovine
}

\section{CIP Programme in Bosnia and Herzegovina: the Experience of the National and University Library of Bosnia and Herzegovina}

\author{
Viktorija Martinčević-Huseinčehajić \\ Nacionalna i univerzitetska biblioteka Bosne i Hercegovine, Sarajevo, Bosna i Hercegovina / National and University Library of \\ Bosnia and Herzegovina, Sarajevo, Bosnia and Herzegovina \\ viktorija@nub.ba
}

\section{Informacije o članku / Article Info}

Primljen / Received 12. 6. 2020.

Prihvaćen / Accepted 3. 8. 2020

Dostupan online / Available online: 15. 12. 2020

Ključne riječi / Keywords:

CIP program, izdavač, biblioteka, CIP zapis,

katalogizacija u publikaciji

CIP programme, publisher, library, CIP record, cataloguing in a publication

\begin{abstract}
Sažetak / Abstract
U članku je predstavljena realizacija CIP programa u Bosni i Hercegovini i njegov značaj za izdavače i biblioteke. Istaknuto je koliko je bitna suradnja između izdavača i biblioteka. Dat je prikaz CIP programa u Bosni i Hercegovini, ali i naznačene smjernice za daljnji rad.
\end{abstract}

The article presents the implementation of the CIP programme in Bosnia and Herzegovina and its significance for publishers and libraries. The importance of cooperation between publishers and libraries was emphasized. An overview of the CIP programme in Bosnia and Herzegovina is given, as well as guidelines for further work.

\section{Uvod}

Sedamdesetih godina prošlog stoljeća javlja se interes za katalogizaciju u publikaciji (u daljem tekstu CIP). Zahvaljujući tehnološkom razvoju, njegovoj primjeni u bibliotekama i potrebi za standardiziranim pravilima za obradu bibliotečke građe te sve većoj izdavačkoj produkciji, započela je realizacija CIP programa. CIP je engleski akronim za Cataloguing in Publication i predstavlja skraćeni kataloški zapis otisnut u publikaciji i izrađen prema međunarodnim pravilima. Svaka država koja ima CIP program pridržava se međunarodnih standarda, preporuka i smjernica međunarodnih organizacija kao što su IFLA (International Federation of Library Associations and Institutions), UNESCO (The United Nations Educational, Scientific and Cultural Organization) i dr. zbog razmjene podataka i razvoja saradnje na međunarodnoj razini. Publikacija je nosilac informacija, a s CIPom poboljšava upotrebu publikacije i ubrzava njenu cirkulaciju, kao i saradnju biblioteka i izdavača. Publikacija se CIP-om uključuje u program nacionalne bibliografske kontrole, zatim univerzalne dostupnosti publikacija i globalni projekat univerzalnog pristupa informacijama.

\section{Introduction}

In the 1970s there was an interest in cataloguing in publication (further in text CIP). Thanks to technological development, its application in libraries and the need for standardized rules for the processing of library materials, as well as increasing publishing production, the implementation of the CIP programme has begun. CIP is the English acronym for Cataloguing in Publication and is an abbreviated catalogue record printed in a publication and made according to international rules. Each country that has a CIP programme adheres to international standards, recommendations and guidelines of international organizations such as IFLA (International Federation of Library Associations and Institutions), UNESCO (The United Nations Educational, Scientific and Cultural Organization), etc. for data exchange and development cooperation at the international level. The publication is a carrier of information, and with the CIP it improves the use of the publication and speeds up its circulation as well as the cooperation of libraries and publishers. The publication is included in the CIP programme of national bibliographic control, then the universal availability of publications and the global project of universal access to information. 


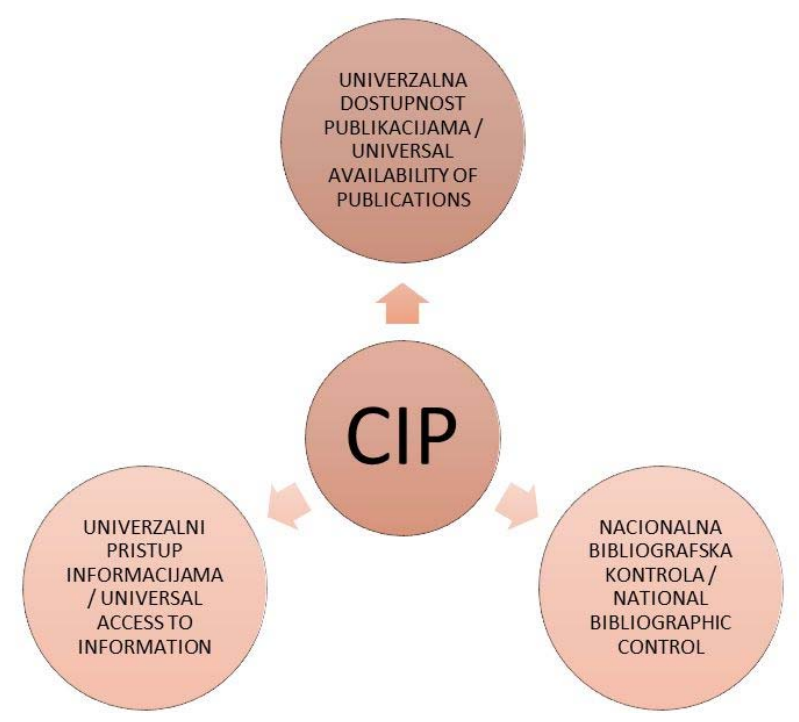

\section{Počeci CIP-a u Bosni i Hercegovini}

CIP program se pojavio u prošlom stoljeću, a inicijatori u bivšoj Jugoslaviji bili su Hrvatska i Makedonija. Katalogizacija u publikaciji u Bosni i Hercegovini pokrenuta je 1986. godine, a nosilac programa je Nacionalna i univerzitetska biblioteka Bosne i Hercegovine sa sjedištem u Sarajevu. Prvi izdavač kojem je dodijeljen CIP i s kojim je biblioteka ostvarila suradnju bila je Svjetlost iz Sarajeva. Kada se CIP program pojavio u Bosni i Hercegovini, predstavljao je zajednički interes za biblioteke i izdavače, a to je da omogući da brza i potpuna informacija o novim naslovima što prije dođe do korisnika.

\section{Značaj za izdavače}

CIP program podrazumijeva stalnu suradnju izdavača i biblioteke. Izdavač želi da zna zašto bi se trebao uključiti u CIP program i što mu taj program omogućuje. Izdavači i biblioteke imaju jedan zajednički interes koji je usmjeren na korisnika. Oboje žele omogućiti da knjiga što prije dođe u ruke korisnika i da imaju brzu i cjelovitu informaciju o novim naslovima, a to je upravo ono što CIP program omogućava.

Izdavači imaju višestruku korist od CIP-a kao npr. izlaženjem CIP biltena - informativne publikacije o novim naslovima, tj. knjigama u štampi, pružajući:

- propagandnu vrijednost - služi kao najava publikacija,

- ekonomsku vrijednost - omogućava bržu prodaju publikacija,

- marketinšku vrijednost - omogućava reklamiranje izdavačke djelatnosti u CIP biltenu.

\section{The beginnings of the CIP in Bosnia and Herzegovina}

The CIP programme appeared in the last century, and the initiators in the former Yugoslavia were Croatia and Macedonia. Cataloguing in the publication in Bosnia and Herzegovina was launched in 1986, and the holder of the programme is the National and University Library of Bosnia and Herzegovina based in Sarajevo. The first publisher to be assigned the CIP and the library cooperated with was Svjetlost from Sarajevo. When the CIP programme appeared in Bosnia and Herzegovina, it was of common interest to libraries and publishers, and that was to enable quick and complete information on new titles to reach users as soon as possible.

\section{Significance for publishers}

The CIP programme implies constant collaboration between publishers and the library. The publisher wants to know why they should join the CIP programme and what that programme allows them to do. Publishers and libraries have one common interest that is user-centered. They both want to enable the book to get into the hands of users as soon as possible and to have quick and complete information about new titles, and that is exactly what the CIP programme allows.

Publishers have multiple benefits from the CIP, such as publishing a CIP Bulletin - informative publications on new titles, i.e. books in print, by providing:

- propaganda value - serves as an announcement of publications,

- economic value - enables faster sale of publications,

- marketing value - enables advertising of the publishing activity in the CIP Bulletin. 
CIP izdavačima pruža mogućnost da izrađuju vlastite izdavačke kataloge, a CIP bilten im pruža uvid u produkciju drugih izdavača.

CIP ima i edukativnu ulogu jer zahtijeva od autora i izdavača da knjigu pripreme prema međunarodnim standardima, što znači da se pridržavaju osnovnih parametara kako i koje podatke staviti na naslovnu stranicu, kako složiti naslov i podnaslov, gdje staviti podatke o odgovornosti, koji se podaci nalaze $u$ impresumu i sl.

\section{Značaj za biblioteke}

Pored navedenog značaja CIP-a za izdavače, CIPima veliko značenje i za biblioteke jer podrazumijeva:

- ujednačenu i standardiziranu obradu katalogizacije i klasifikacije knjiga,

- racionalizaciju poslovanja u biblioteci, što znači bržu obradu, smanjenje troškova, bržu i bolju nabavu,

- obavijest o novim naslovima putem biltena,

- služi za kontrolu pristizanja obaveznog primjerka,

- osnovu za tekuću nacionalnu bibliografiju.

Korištenjem CIP-a smanjuje se vrijeme katalogiziranja. CIP zapis sadrži provjerene bibliografske podatke i na taj način osigurava tačnost i kvalitetu (Pšenica 1994, 24).

\section{Izrada CIP zapisa}

CIP je kataloški opis otisnut u publikaciji koji se izrađuje tijekom završne pripreme izdavanja knjige. Kao predložak koristi se konačni prijelom pripremljen za štampu. Na taj način knjiga, koja je već nosilac informacija s CIP-om, dobija dodatnu dimenziju informiranja koja umnogome poboljšava upotrebu knjige, odnosno njenu cirkulaciju na relaciji izdavač - biblioteka - korisnik.
The CIP provides an opportunity for publishers to create their own publishing catalogues, and the CIP Bulletin provides them with insight into the production of other publishers.

CIP also has an educational role because it requires authors and publishers to prepare the book according to international standards, which means that they adhere to the basic parameters of how and what information to put on the title page, how to put the title and subtitle, where to put responsibility information, what information is in imprint, etc.

\section{Significance for libraries}

In addition to the importance of the CIP for publishers, the CIP is also of great importance for libraries because it implies:

- uniform and standardized processing of cataloguing and classification of books,

- rationalization of business in the library, which means faster processing, cost reduction, faster and better acquisition,

- notification of new titles via CIP Bulletin,

- serves to control the arrival of a mandatory copy,

- basis for the current national bibliography.

Using CIP reduces cataloguing time. The CIP record contains verified bibliographic data and thus ensures accuracy and quality (Pšenica 1994, 24).

\section{Creating CIP records}

A CIP is a catalogue description printed in a publication that is produced during the final layout of a book publishing. A final print-ready layout is used as a template. In this way, the book, which is already a carrier of information with the CIP, gets an additional dimension of information that greatly improves the use of the book and its circulation in the publisher - library - user relationship.

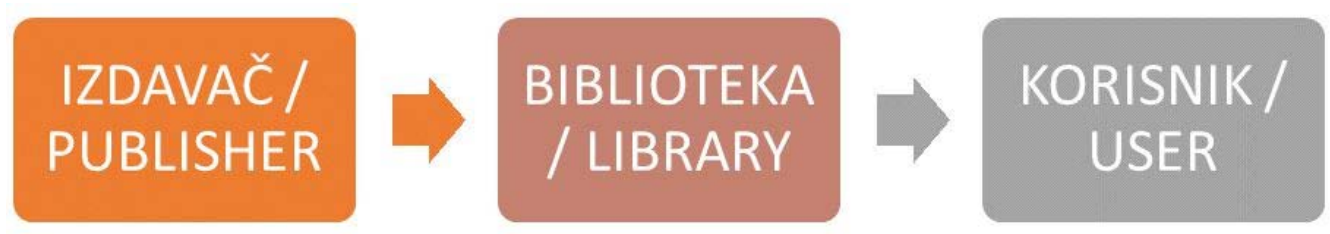

CIP zapis izrađuje se na temelju podataka sadržanih u publikaciji pripremljenoj za štampu. Za potrebe formalne i sadržajne obrade, kako bi se dobili što potpuniji i tačniji bibliografski podaci, izdavač/nakladnik treba dostaviti konačan prijelom knjige pripremljene za štampu/tisak nakon posljednje korekture s jasno definisanom naslovnom stranom (3. strana u knjizi) i potpunim impresumom u PDF formatu.
The CIP record is made on the basis of the data contained in the publication prepared for printing. For the purposes of formal and subject processing, in order to obtain the most complete and accurate bibliographic data, the publisher should submit the final copy of the book prepared for printing after the last proofreading with a clearly defined title page ( $3^{\text {rd }}$ page in the book) and a complete imprint in PDF format. 
Osnovni podaci za identifikaciju publikacije su naslov, podnaslov, podaci o odgovornostima, podatak o izdanju, godina izdavanja, paginacija, zbirka, originalni naslov, ISBN broj. Prvi i najvažniji element je odrednica (osobna, korporativna, stvarna ili formalna), nakon koje slijedi bibliografski opis.

\section{Oblik CIP zapisa}

$\mathrm{Na}$ vrhu je uvodna kratica CIP s nazivom na jeziku i pismu ustanove, oznakom zemlje i ureda koji izrađuje CIP.

Nakon toga slijedi UDK.

Zatim slijedi odrednica glavne kataložne jedinice, pa bibliografski opis koji se temelji na ISBD standardima.

Na kraju zapisa se nalaze oznake, tj. ISBN broj i ID broj zapisa.
The basic data for the identification of the publication are the title, subtitle, data on responsibilities, data on the edition, year of publication, pagination, collection, original title, ISBN number. The first and most important element is the heading (personal, corporate, actual or formal) followed by a bibliographic description.

\section{CIP record format}

At the top is the introductory abbreviation CIP with the name in the language and script of the institution, the name of the country and the office that assigns the CIP.

This is followed by the UDC.

Then follows the heading of the main cataloguing unit, followed by a bibliographic description based on ISBD standards.

At the end of the record there are tags, i.e. ISBN number and ID number of the record.
CIP - Katalogizacija u publikaciji

Nacionalna i univerzitetska biblioteka

Bosne i Hercegovine, Sarajevo

821.163.4(497.6)-992

012 Ovčina I.

OVČINA, Ismet

Putovanja i saznanja : od Katara do Islanda / Ismet Ovčina. - Sarajevo : Nacionalna i

univerzitetska biblioteka Bosne i Hercegovine, 2020. - 254 str. : fotogr. ; $30 \mathrm{~cm}$. - (Edicija

Memoria Mundi)

ISBN 978-9958-500-97-8

COBISS.BH-ID 38577158 naziv i sjedište institucije koja dodjeljuje CIP name and place of the institution which assigned CIP

stručna oznaka $=$ UDK

classification $=$ UDC

autorska odrednica | main entry

bibliografski opis | bibliographic description

\section{ISBN broj | ISBN number}

identifikacijski broj zapisa u bazi podataka identification number of records in the database
CIP je prvi kataloški zapis koji se kasnije u procesu obrade koristi i nadopunjuje za potrebe bibliografije. Bibliografska kontrola treba da unapređuje izradu jednog bibliografskog zapisa za svaku publikaciju, uklanjajući dupliciranje zapisa, i osigura međunarodno kompatibilne i dostupne zapise. CIP omogućuje to jer se svaka publikacija katalogizira jednom, i to u zemlji gdje se izdaje.

\section{CIP program u Bosni i Hercegovini danas}

U Federaciji Bosne i Hercegovine CIP se dodjeljuje u Sarajevu pri NUBBiH.

U Bosni i Hercegovini bilježimo porast broja
CIP is the first catalogue record that is used later in the processing and complemented for the purposes of bibliography. Bibliographic control should enhance the production of one bibliographic record for each publication, eliminating duplication of records, and ensure internationally compatible and accessible records. The CIP makes this possible because each publication is catalogued once in the country where it is published.

\section{CIP programme in Bosnia and Herzegovina today}

In the Federation of Bosnia and Herzegovina, the CIP is assigned in Sarajevo in the NUBBIH. 
izdavača, kao i promjene vezane za nove tehnologije u izdavačkoj djelatnosti. Naime, sve više se traži CIP za elektronska izdanja i sve je veći broj autora izdavača.
In Bosnia and Herzegovina, we are recording an increase in the number of publishers as well as changes related to new technologies in the publishing industry. Namely, CIP for electronic editions is increasingly requested and there is an increasing number of authors-publishers.

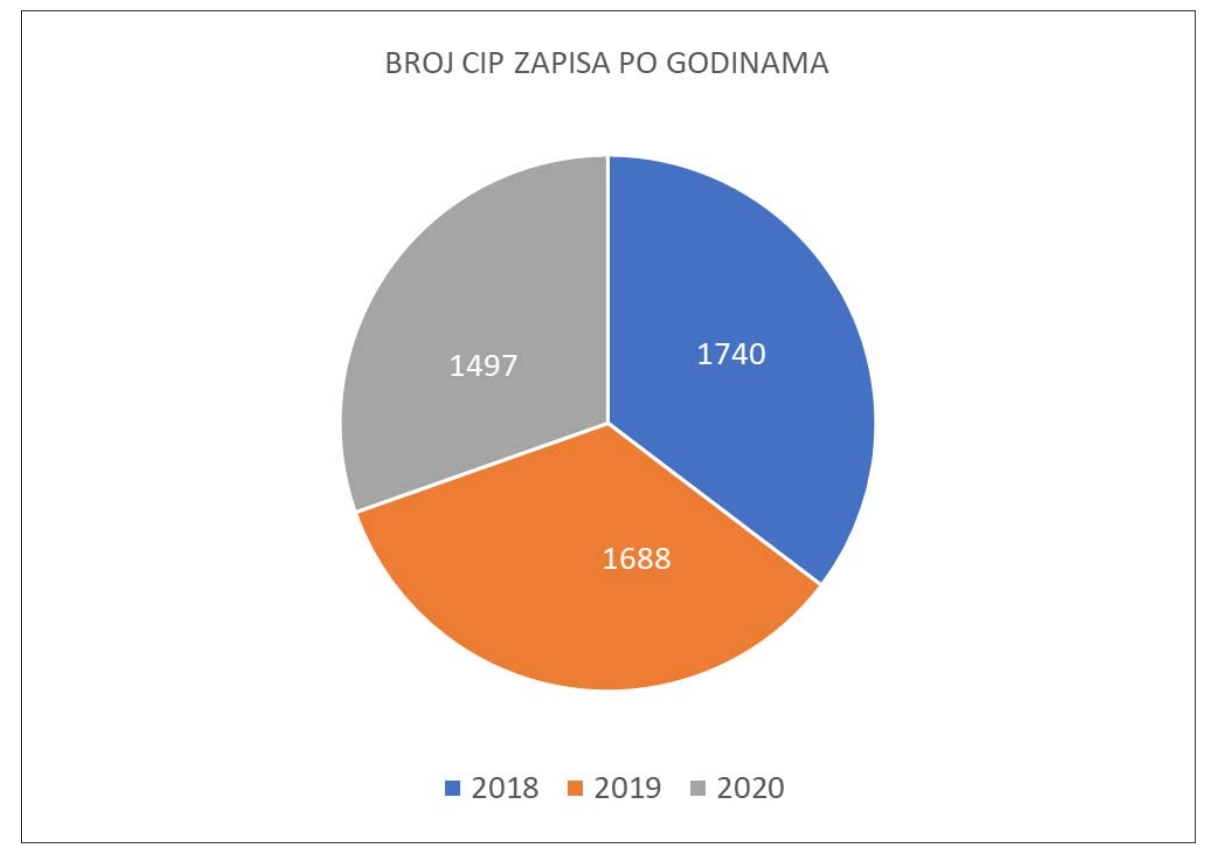

* Podaci preuzeti iz COBISS-a | Data retrieved from COBISS

Također, najviše se izdaju djela iz književnosti i društvenih nauka, a najmanje iz prirodnih nauka i umjetnosti, što je vidljivo iz sljedećeg grafikona.
Also, the most published works are from literature and social sciences, and the least from natural sciences and arts, which can be seen from the following chart.

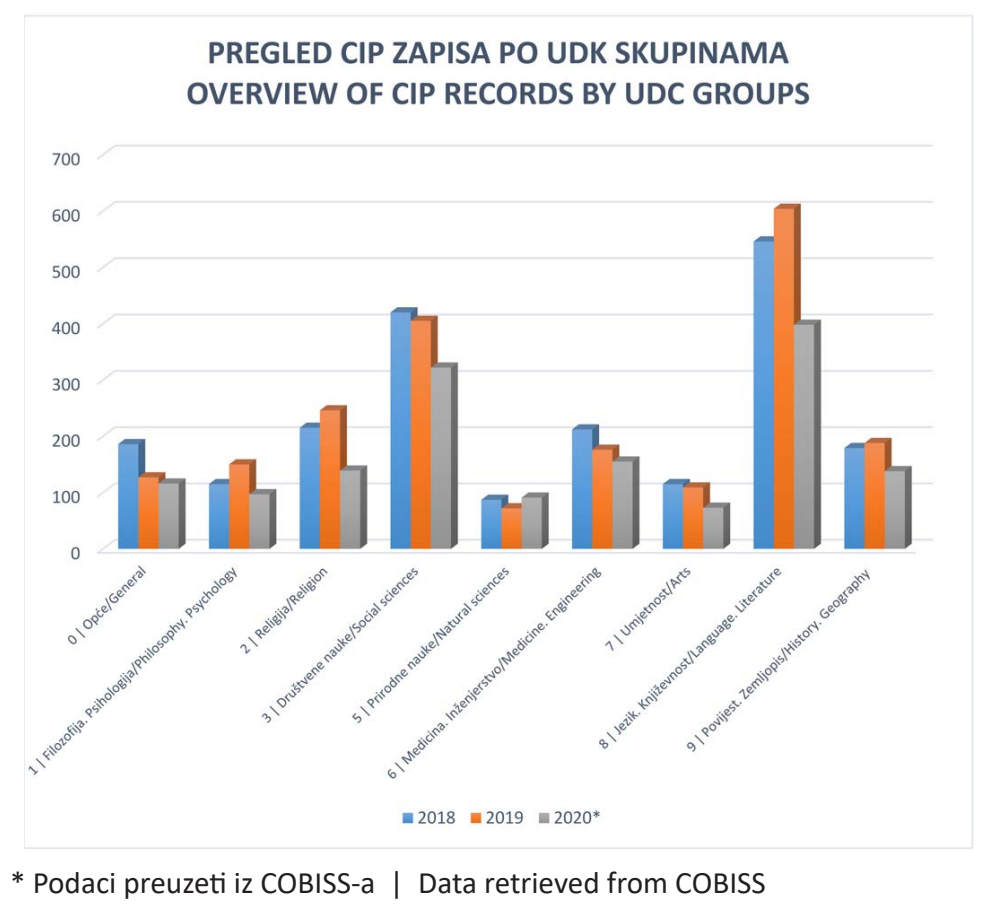


Dosadašnja iskustva pokazuju da neki izdavači ne izvršavaju svoju obavezu prema NUBBiH jer ne šalju redovno ili uopće ne šalju obavezne primjerke. $\mathrm{Za}$ posljedicu imamo poteškoće u poslovanju biblioteke, što se odražava na fond i nepotpunost tekuće bibliografije.

Još jedan od razloga za razvijanje saradnje između izdavača i biblioteke jeste taj što se često ne poštuju zahtjevi bibliotekara, pa dolazi do nepotrebnih intervencija u CIP zapisu koji je zbog toga više ili manje netačan. Postoje situacije kada izdavač ne dostavi konačan prijelom publikacije, ne navede sve podatke potrebne za obradu ili su ti podaci pogrešni, te zbog toga opada kvalitet CIP-a, a samim tim i njegova upotrebljivost. Česte su situacije kada izdavači nakon već dodijeljenog CIP-a izvrše izmjene, čak i samog naslova, a ne obavijeste CIP centar o urađenim izmjenama i tada imamo potpuno neupotrebljiv zapis u bazi podataka. Izdavači nekada uopće ne kontaktiraju s CIP centrom i štampaju publikacije bez CIP-a ili ubacuju stare CIP-ove od prijašnjih izdanja, a nerijetko sami izrade CIP koristeći naše ime u zaglavlju, što je nedopustivo i predstavlja neovlašteno korištenje tuđeg imena. Još jedan od problema koji se javlja jeste prenos CIP zapisa u knjigu. Izdavači često na svoju ruku pomjeraju zapis, a onda to više nije zapis urađen prema standardima (Pšenica 1994, 28).

\section{CIP bilten}

CIP bilten u BiH izlazi jednom mjesečno od januara 2019. godine na web stranici NUBBiH www.nub. ba i omogućava uvid u izdavačku djelatnost $\mathrm{BiH}$ svijetu te pruža uvid u produkciju drugih izdavača. CIP zapisi su raspoređeni prema Univerzalnoj decimalnoj klasifikaciji (UDK), a unutar pojedinih stručnih grupa jedinice su razvrstane abecedno. Svaki broj Biltena uključuje i registar autora. $\mathrm{BiH}$ nema normativnu datoteku, pa se nadam da će registar autora u Biltenu olakšati u budućnosti izradu normativne datoteke, odnosno poslužiti kao temelj za nju.

Bilten kao prva informacija o knjigama u štampi može poslužiti u planiranju nabavke u bibliotekama i knjižarama, ali i kao informativni katalog.

\section{Budućnost CIP zapisa}

Uvijek je postojalo nekoliko nedoumica vezanih za CIP, ali i samu izradu zapisa. Problemi na koje nailazimo su stručni ili bibliotečki i formalni ili izdavački.

Prvo pitanje je da li je potrebno skratiti ili proširiti CIP zapis?
Experience gained so far shows that some publishers do not fulfil their obligation to NUBBIH because they do not send regularly nor mandatory copies at all. As a result, we have difficulties in the operation of the library, which is reflected in the fund and the incompleteness of the current bibliography.

Another reason for developing cooperation between publishers and the library is that the requirements of librarians are often not respected, so there is unnecessary intervention in the CIP record, which is therefore more or less inaccurate. There are situations when the publisher does not submit the final copy of the publication, does not provide all the data necessary for processing or these data are incorrect, and therefore the quality of the CIP, and thus its usability, decreases. There are often situations when publishers make changes, even the title itself, after already assigned CIP, and do not notify the CIP centre about the made changes, and then we have a completely unusable record in the database. Publishers sometimes do not contact the CIP centre at all and print publications without a CIP or insert old CIPs from previous editions, and often create their own CIP using our name in the header, which is unacceptable and the unauthorized use of someone else's name. Another problem that arises is the transfer of CIP records to the book. Publishers often move the record on their own, and then it's no longer a record made to standards (Pšenica 1994: 28).

\section{CIP Bulletin}

The CIP Bulletin in BIH is published once a month since January 2019 on the NUBBIH website www. nub.ba and provides insight into the publishing activity of BIH to the world, and provides insight into the production of other publishers. CIP records are arranged according to the Universal Decimal Classification (UDC), and within individual professional groups the units are classified by alphabet. Each issue of the Bulletin includes a register of authors. BIH does not have an authority file, so I hope that the register of authors in the Bulletin will facilitate the creation of an authority file in the future, i.e. serve as a basis for it.

The Bulletin as the first information about books in print can be used in planning purchases in libraries and bookstores, but also as an informative catalogue.

\section{The future of CIP records}

There have always been a few doubts about the CIP, but also the making of the record itself. The problems we encounter are professional or library and formal or publishing. 
Zbog gore navedenih problema smatram da se treba ići na skraćivanje zapisa, a da se dolaskom publikacije putem obaveznog primjerka on proširuje. Potrebno je zakonski odrediti obaveze izdavača, kao i naplatu usluga za CIP.

Potrebno je educirati izdavače, tj. izdati uputstva koja bi bila od pomoći posebno tek registrovanim izdavačima ili autorima koji izdaju knjigu u vlastitom izdanju te svima koji se bave izdavačkom djelatnošću. Na taj bismo način uveliko smanjili nedoumice $\mathrm{i}$ probleme na koje nailazimo $\mathrm{u}$ svakodnevnoj komunikaciji.

Drugo pitanje je da li se u CIP zapis treba uvesti predmetnica, jer je činjenica da je predmetni katalog zasjenio stručni katalog. Korisnici žele što prije doći do tačne i potpune informacije, a mi kao bibliotekari to im moramo i omogućiti.

Problemi vezani za izdavače javljaju se jer se predlošci donose u posljednji čas, često nepotpuni, ne pridržavaju se tačnog ispisa interpunkcijskih znakova, čak ih i mijenjaju zajedno s određenim podacima bez znanja bibliotekara. Izdavači često znaju reći da im CIP zapis kvari publikaciju, zauzima mjesto i sl. pa štamparije preslože CIP zapis i kada knjiga bude odštampana, kasno je da se nešto promijeni. Smatram da bi trebalo izostaviti skupinu materijalnog opisa, jer upravo u tom području nailazimo na najveći broj izmjena.

\section{Zaključak}

Katalogizacijom u publikaciji ubrzava se i unapređuje proces obrade knjige, što omogućuje da knjiga što prije dođe do svojih korisnika. Na međunarodnom planu CIP program se odvija uspješno uz dobru saradnju izdavača i biblioteka. Sve je veća potreba za CIP zapisima za neknjižnu građu. Važan alat za uspješno odvijanje programa trebalo bi biti uputstvo za izdavače kako bi što kvalitetnije prema standardima uradili prijelom publikacija i izbjegli neugodnosti prilikom rada. Svaka zemlja koja ima nacionalni centar za CIP dužna je pratiti i prihvatiti preporuke i standarde koje koordinira IFLA, jer nema međunarodnog centra za CIP. Potrebno je nastaviti raditi na promicanju CIP-a i zajednici izdavača i bibliotekara. Na kraju možemo naglasiti da je potrebna što operativnija suradnja CIP službe s izdavačima u svrhu što boljeg poslovanja.
The first question is whether it is necessary to shorten or expand the CIP record? Due to the above mentioned problems, I believe that the record should be shortened, and that with the arrival of the publication, it should be expanded through a mandatory copy. It is necessary to legally determine the obligations of the publisher as well as the cost for CIP services.

It is necessary to educate publishers, i.e. to issue instructions that would be especially helpful to newly registered publishers or authors-publishers, and to all those who are engaged in publishing. In that way, we would greatly reduce the doubts and problems we encounter in everyday communication.

Another question is whether a subject terms should be introduced in the CIP record, because the fact is that the subject catalogue has overshadowed the special catalogue. Users want to get accurate and complete information as soon as possible, and we as librarians must provide that.

Problems related to publishers occur because templates are brought at the last minute, often incomplete, do not adhere to the correct printing of punctuation marks, and even are changed together with certain data without the knowledge of the librarian. Publishers often say that the CIP record spoils their publication, takes up space, etc., so the printing houses rearrange the CIP record, and when the book is printed, it is too late to change anything. I think that the group of material description should be left out, because precisely in this area we encounter the largest number of changes.

\section{Conclusion}

Cataloguing in a publication speeds up and improves the process of book processing, which enables the book to reach its users as soon as possible. At the international level, the CIP programme is running successfully with good cooperation between publishers and libraries. There is a growing need for CIP records for non-book material. An important tool for the successful conduct of the programme should be a guide for publishers in order to break down publications as well as possible according to the standards and avoid inconveniences during work. Every country that has a national CIP centre is required to follow and accept the recommendations and standards coordinated by IFLA, as there is no international CIP centre. There is need to continue to promote the CIP and cooperation between publishers and libraries. Finally, we can emphasize that the most operational cooperation of the CIP service with publishers is needed for the purpose of better business. 


\section{Bibliografija / Bibliography}

- Pšenica, D. 1994. "Značenje CIP programa i njegova realizacija u Hrvatskoj" U Značenje CIP-a i ISBN-a za izdavaštvo i knjižničarstvo, urednice Dorica Blažević, Davorka Pšenica, 2139. Zagreb: Nacionalna i sveučilišna knjižnica.
- IZUM - Institut informacijskih znanosti https://plus.bh.cobiss.net/OPAC7/bib/search?q 